\title{
Incentive schemes for school attendance in rural Bangladesh
}

\section{Sajeda Amin}

Population Council

Gilda Sedgh

Follow this and additional works at: https://knowledgecommons.popcouncil.org/departments_sbsr-pgy

Part of the Demography, Population, and Ecology Commons, Education Commons, Family, Life Course, and Society Commons, and the International Public Health Commons How does access to this work benefit you? Let us know!

\section{Recommended Citation}

Amin, Sajeda and Gilda Sedgh. 1998. "Incentive schemes for school attendance in rural Bangladesh," Policy Research Division Working Paper no. 106. New York: Population Council. 


\section{Incentive Schemes for School Attendance in Rural Bangladesh}

Sajeda Amin

Gilda Sedgh

1998 No. 106 


\title{
Incentive Schemes for School Attendance in Rural Bangladesh
}

\author{
Sajeda Amin \\ Gilda Sedgh
}

Sajeda Amin is Associate, Policy Research Division, Population Council. Gilda Sedgh is a Sc.D. candidate at the Harvard School of Public Health.

An earlier version of this paper was presented at the session on Children's Schooling in LDCs, at the Annual Meeting of the Population Association of America, New Orleans, 1996. Funding for this study was provided by the Rockefeller Foundation. 


\begin{abstract}
This paper examines the impact of two incentive schemes on school attendance in rural Bangladesh: a food-for-education program for poor primary school children and a female secondary school scholarship scheme. The data come from an in-depth village study, before and after the programs went into effect. Both programs provide direct financial incentives to families to send their children to and keep them in school. The data also allow for an assessment of an informal school program sponsored by BRAC, a national nongovernmental institution, at the study sites. School enrollment in the target population increased more rapidly than would have been predicted by long-term trends and coincided with the introduction of the incentives. Furthermore, the school incentives resulted in marriage delays for young girls. Qualitative evidence also documents a change in perceptions about the importance of education for underprivileged groups in society.
\end{abstract}

This material may not be reproduced without written permission from the authors. 
This paper examines the changing social environment surrounding investments in children in rural Bangladesh. The site of an earlier village study (1991-92) that found evidence of rapid fertility decline was revisited in 1995 and 1996 with the purpose of conducting a new study on children's education. The study allows us to explore the impact of policy interventions related to investments in children's schooling. The most striking initial observation, confirmed in a community-wide census and a follow-up survey of children, was a substantial increase in school enrollment during the three years since the initial village study. Analysis of qualitative and quantitative data leads us to conclude that much of the rising enrollment and retention in school may be attributed to several monetary incentive schemes introduced in the country in 1994 that were tied to school attendance and targeted to specific underprivileged groups.

Two large government programs were introduced: a food-for-education program for primary school age children and a female secondary school scholarship scheme. Both programs offer direct incentives to families to send their children to and keep them in school. A nongovernmental program of informal primary education may also have helped to increase school attendance.

Changes in education policy such as the ones that have occurred in Bangladesh provide a unique opportunity to study factors that affect investments in children. They represent exogenous influences on a household's decisionmaking about children's schooling. Justification for the programs was based on the assessment that certain structural and familial factors act as barriers to schooling of children. The costs of schooling to families include direct costs for fees and books, as well as the more indirect costs of higher standards of nourishment and clothing that are perceived to be a necessary condition of attendance. Second, there are opportunity costs since children engage in various productive activities from an early age, and schooling 
either translates into very long workdays for children or foregone income for the family (Amin 1996a). Under-investment in education may also be related to low expected returns from schooling: where school quality is poor, levels of learning are low and the prospects for improved earnings as a result of schooling are limited.

The schooling of adolescent girls involves additional parental concerns. When schooling delays marriage, it may reduce the desirability of girls in the marriage market: while education is a valued attribute, so is young age at marriage for girls. Perceived risks are also associated with sexual safety. A girl whose sexual virtue has been compromised, in addition to suffering the psychological costs, also faces diminished prospects for marriage. Safety issues related to traveling to schools that are sometimes several kilometers away from the village is reported to be a significant factor in the decision not to send girls to secondary school. These costs generally outweigh the benefits of schooling, namely higher status, better opportunities for work in the formal sector, and better marriage prospects.

Thus, in Bangladesh as in many other impoverished agrarian societies, the level of investment in children is the outcome of a complex decisionmaking process where parents' ability and desire to invest in children are related to costs of education, opportunity cost of children's time in school for the household, and expectations regarding returns to education. The social setting within the community and the macroeconomic environment also have a significant impact on the level of investment in and demand for schooling. In particular, the aggregate level of schooling in the community is likely to affect perceptions of costs of and returns to schooling. The presence of educated individuals offers direct evidence of what education can and can- 
not buy in terms of opportunities and lifestyle. In most of rural Bangladesh, access to new employment opportunities, such as working for rural extension projects in agriculture, health, or credit, depends critically upon levels of education.

This paper addresses one aspect of the many factors that affect education-specifically, can governments increase investment in children by changing the short-run costs of education? We explore this question through quantitative and qualitative data that focus on parental perceptions of costs and benefits of education and other factors that influence this decision.

\section{BACKGROUND}

This study uses data from two villages in Mohanpur Thana, Rajshahi District, Rajshahi Division, in northern Bangladesh. The two villages had a combined population of 4,002 in July 1995. The study area, referred to hereafter as Villages A and B, are both primarily agricultural communities with some occupational diversification evident in both. Village B is a roadside village within a half-hour bus ride from the regional town. As elsewhere in Bangladesh, land is cultivated intensively, and increasing pressure on land is a major factor underlying social and economic change (Amin 1996b). Few households rely on agriculture alone; wage laborers perform a combination of agricultural and nonagricultural tasks.

In the past two decades the villages have experienced considerable development activities in the areas of health, family planning, and microcredit for women. Both villages have good access to health and family planning services by rural Bangladeshi standards. Village A is within $2 \mathrm{~km}$ of the 
Thana health complex; Village B, although $15 \mathrm{~km}$ from the Thana headquarters, has a Union-level family welfare center. ${ }^{1}$ Rajshahi Division had the earliest onset of fertility decline in Bangladesh: both villages have contraceptive prevalence rates exceeding 60 percent, considerably higher than the national average but consistent with the average for the region. The villages have good access to children's immunization services as well.

It is likely that the activities of several nongovernmental development organizations in the area have been an important force for social change in these villages. Over 50 percent of households in the study area belonged to one or more of four development organizations in 1995. In 1992 the level of NGO membership and influence was considerably lower. Although recent assessments have raised skepticism about the economic impact of NGO programs on poverty alleviation or overall development (Sobhan 1995), they have an undeniable social influence in these villages that may well help to change attitudes toward children's education. There is increased interaction with the world outside the village; these organizations undertake campaigns and programs with the explicit purpose of raising awareness about such issues as poverty, gender inequality, education, and health. NGO credit schemes also increase and regularize the flow of cash within the village economy.

Despite these changes the two communities remain traditional in many respects. As a result of the sharp sexual division of labor, women's participation in the labor market is very low (Amin 1997). Family living arrangements remain patrilineal (Amin 1996b), and the rise of a new and oppressive marriage practice, dowry demands on the bride's family, that can be traced to a marriage squeeze brought about by demographic change, has pernicious collective consequences for adolescent girls (Amin and Cain 1997). 
Although each of the villages now has a primary school, education in the past was affordable only for the elite, and a handful of households sent their children to school. As a result, education and literacy among all adults is low, and more so for women. Thus, the policy interventions in education have to be seen in a context of low parental education in these villages.

\section{The Primary and Secondary School System}

Our study villages are representative of villages in Bangladesh in having one government primary school in each. There are four or five teachers in each primary school. Books are provided free and no primary school fees are required. A small examination fee and an activities fee are collected at the beginning of the term. Most primary schools do not have dress codes or uniforms. Although children are expected to start primary school at age six, entrance rules are not rigid and children typically start anywhere from age six to eight years or even later.

The two villages are also representative of rural Bangladesh in their access to secondary (grades 6-10) and higher secondary schools (grades 11 and 12). Although most of these institutions are private enterprises, they receive substantial government subsidies. Village B has one secondary school, but the nearest schools to Village A are in the Thana Headquarters about 2 $\mathrm{km}$ away. Secondary schools are free for girls but entail fees for boys. Books have to be bought by the student, and admissions fees and examination fees are imposed on both girls and boys. Like most schools in the country, these schools have dress codes and required uniforms. All students sit for national examinations at the end of grades 10 and 12 . 
The language of instruction is Bengali. English is taught as a second language beginning in primary school, and there is compulsory religious (Islamic) education at the secondary level. Starting from third grade, students must pass a school-administered annual examination to proceed to the next grade. Failure to take the examination or to pass it results in grade repetition.

BRAC schools. BRAC (Bangladesh Rural Advancement Committee), a large national NGO, conducts an innovative program for school dropouts through an informal primary education scheme. In 1995 there were 30,000 schools covering 900,000 students nationwide. BRAC schools are one-room classes of 30 students that give preferential enrollment to girls and to children from poor families. The teacher is usually a woman from the village with at least an eighth grade education who has completed an intensive teacher training course run by BRAC. The program's policy is to maintain a 70-30 ratio of girls to boys among those enrolled. BRAC schools make an effort to enroll dropouts from the regular school system, and the curriculum developed by BRAC is intended to provide gender-sensitive, functional education. Two BRAC schools in Village A were opened in 1993 and 1994, and two schools following the BRAC model were set up in Village B in $1996 .{ }^{2}$ BRAC provides all books and stationery required for school free of cost, and there are no examination fees. Grade repetition is not permitted.

Food for education. In 1994 the Government of Bangladesh initiated an incentive scheme that entitles children of poor families to $15 \mathrm{~kg}$ of wheat each month if they enroll in primary school and maintain 85 percent attendance. ${ }^{3}$ The wheat is given to the parents of children selected by a school management committee and approved by the local authority. The distribution program is managed by local government functionaries. Poor families 
are selected by occupational and landholding criteria and include femaleheaded households, and the program tries to reach the poorest 40 percent of all rural children. Nationally, this program was initiated in two of eight Unions in 460 Thanas in the country. In our study area, only Village B is covered by the program. Analyses of enrollment trends in this village over time, particularly in families that are eligible for program benefits, provide evidence of the impact of the food-for-education scheme.

Female secondary school scholarship scheme. The government also initiated a scholarship scheme in 1994 for all girls enrolled in grades 6 and 9. This scheme was extended to girls in grades 7 and 8 starting in 1996. Entitlement to scholarships requires 65 percent school attendance and maintenance of a certain grade average in the previous year, but there are no criteria for economic exclusion. Schools receive a subsidy for each girl enrolled under this program, and the girls receive a monthly stipend deposited in their bank accounts. The stipend ranges from \$1-2 depending on grade, and is of considerably lesser value than the wheat rations that children receive in primary school, which have a market value of \$2-4. Parents of scholarship recipients are required to sign a bond guaranteeing that the girls will not be married before reaching 18 years of age. This program has been introduced throughout Bangladesh and thus it affects children of secondary school age in both study villages.

Table 1 summarizes the study villages' access to these education programs in 1992, 1995, and 1996. None of these programs was in effect in 1992; thus the enrollment and education rates for that year can be used as baseline figures in our subsequent evaluation. 
Table 1 School programs in study villages, 1992, 1995, and 1996

\begin{tabular}{|c|c|c|c|c|}
\hline & \multicolumn{2}{|c|}{ Village A } & \multicolumn{2}{|c|}{ Village B } \\
\hline & Females & Males & Females & Males \\
\hline 1992 & No program & No program & No program & No program \\
\hline \multirow[t]{2}{*}{1995} & $\begin{array}{l}\text { BRAC } \\
\text { (primary school) }\end{array}$ & $\begin{array}{l}\text { BRAC } \\
\text { (primary school) }\end{array}$ & $\begin{array}{l}\text { Food-for- } \\
\text { education } \\
\text { (primary school) }\end{array}$ & $\begin{array}{l}\text { Food-for- } \\
\text { education } \\
\text { (primary school) }\end{array}$ \\
\hline & $\begin{array}{l}\text { Female secondary } \\
\text { school scholarship } \\
\text { scheme } \\
\text { (secondary school) }\end{array}$ & & $\begin{array}{l}\text { Female secondary } \\
\text { school scholarship } \\
\text { scheme } \\
\text { (secondary school) }\end{array}$ & \\
\hline \multirow[t]{3}{*}{1996} & $\begin{array}{l}\text { BRAC } \\
\text { (primary school) }\end{array}$ & $\begin{array}{l}\text { BRAC } \\
\text { (primary school) }\end{array}$ & $\begin{array}{l}\text { Food-for- } \\
\text { education } \\
\text { (primary school) }\end{array}$ & $\begin{array}{l}\text { Food-for- } \\
\text { education } \\
\text { (primary school) }\end{array}$ \\
\hline & $\begin{array}{l}\text { Female secondary } \\
\text { school scholarship } \\
\text { scheme } \\
\text { (secondary school) }\end{array}$ & & $\begin{array}{l}\text { Female secondary } \\
\text { school scholarship } \\
\text { scheme } \\
\text { (secondary school) }\end{array}$ & $\begin{array}{l}\text { BRAC } \\
\text { (franchise programs) }\end{array}$ \\
\hline & & & $\begin{array}{l}\text { BRAC } \\
\text { (franchise programs) }\end{array}$ & \\
\hline
\end{tabular}

\section{DATA}

Surveys conducted in 1992, 1995, and 1996 allowed us to examine the impact of the two government-sponsored programs established in 1994 (the food-for-education program and the female secondary school scholarship program) and the BRAC schools on enrollment and other schooling indicators. The 1996 survey was administered to all children between the ages of 6 and 19 and additionally included questions on school-related expenses, an aptitude module, and a module on knowledge and attitudes about marriage and fertility.

Four out of a total of ten neighborhoods in the two villages were selected for in-depth study. A sample of one in every four male-headed house- 
holds and all female-headed households were identified for detailed case studies in the 1992 survey. Every sample household with at least one member between ages 10 and 25 was revisited in 1995 for open-ended in-depth interviews on education that were taped, transcribed, and translated. Wherever possible, interviews were conducted with pairs of mothers and children. Topics covered by the in-depth interviews included school attendance, work conflict with school, reasons for school dropout, marriage history and conflict with schooling (if relevant), school quality assessment, values and aspirations, and information on the new school programs.

In the remainder of this paper we discuss the extent to which the initiation of these incentive schemes has been able to overcome the cost barriers to education and/or boost the perceived and real benefits of schooling.

\section{RESULTS}

Before reaching the study site, we were briefed in Dhaka about the BRAC programs and the two national educational incentives. To assess the reach of these programs, we added a question at the end of each in-depth interview session about whether the respondents had heard about BRAC schools and the two government programs. The responses overwhelmingly indicated not only that the programs were very familiar to the village residents, but also that respondents spontaneously attributed recent changes in enrollment to the programs. These responses served as the motivation for the present paper, which explores the impact of these education schemes on children's schooling. Following are examples of statements from village respondents about the incentive programs: 
Bakul (17-year-old male who dropped out of school in Class 5 in Village B):

The number of students has gone up now that they are giving wheat. Everybody goes to school for the wheat. I have heard that the government is giving money to girls in high school. They have done a good thing. It is benefiting all. Earlier, they wouldn't be educated because of the lack of money and they would be married off. But now that is no longer the case.

Fazil (23-year-old male in Village B):

Those who are poor get wheat. Not everybody gets it. They cut wheat out if you don't go to school one day. They give money to girls in high school. It's good that they are giving money. Not everybody could go to school before, now they can.

Delwar (21-year-old male school dropout in Village B):

It's been good for the girls. Everybody is now able to study. Earlier a lot of people couldn't go because they couldn't afford to. Now they are all studying. They are giving money. Some are getting Tk. 300, some even more. The government is giving everybody an opportunity to study.

Mother of an 11-year-old male school dropout in Village A:

I have heard from people about the wheat distribution. They don't give it in this school. You never know if the teachers have taken it all.

Mother of a 20-year-old female recently married in Village A:

I have heard about the scholarship and the wheat. But the school does not give wheat. 
These comments from the in-depth interviews suggested to us that the programs had affected both villages with some force, and that while they may have overshadowed perceptions about other factors affecting education, it was worth exploring the validity of the assertion that these programs had an impact on actual enrollment. In the following section we compare enrollment among boys and girls in the two villages both cross-sectionally and over time.

\section{Enrollment in School}

The most striking finding regarding trends in enrollment over time is that the proportion of 6-19-year-olds who have never attended school has declined sharply since 1992, for both sexes and in both villages. Figure 1 shows the school enrollment status of children aged 6-19 by year, village, and sex. Enrollment status is defined as never attended school, ever attended but no longer in school, enrolled in secondary school, and enrolled in primary school. While in 1992 32-38 percent of all children had never been to school, this figure dropped to 2-8 percent in 1996. Thus the perception of rapid change in school enrollment is borne out at least in terms of the proportion of children who have ever attended school. Figure 1 also indicates that enrollment in primary school has increased substantially in both villages. Increases in primary school enrollment in Village B coincide with the introduction of the wheat-for-education program and the secondary school scholarship program for girls. Primary school enrollment rates in Village B increased more sharply for girls during this period: the rate increased from 44 percent to 59 percent for girls and from 50 percent to 55 percent for boys.

The figure also suggests that increased primary school attendance resulted in higher rates of completion as well as increased secondary school 
Figure 1 School attendance status of 6-19-year-olds by village and gender, Mohanpur
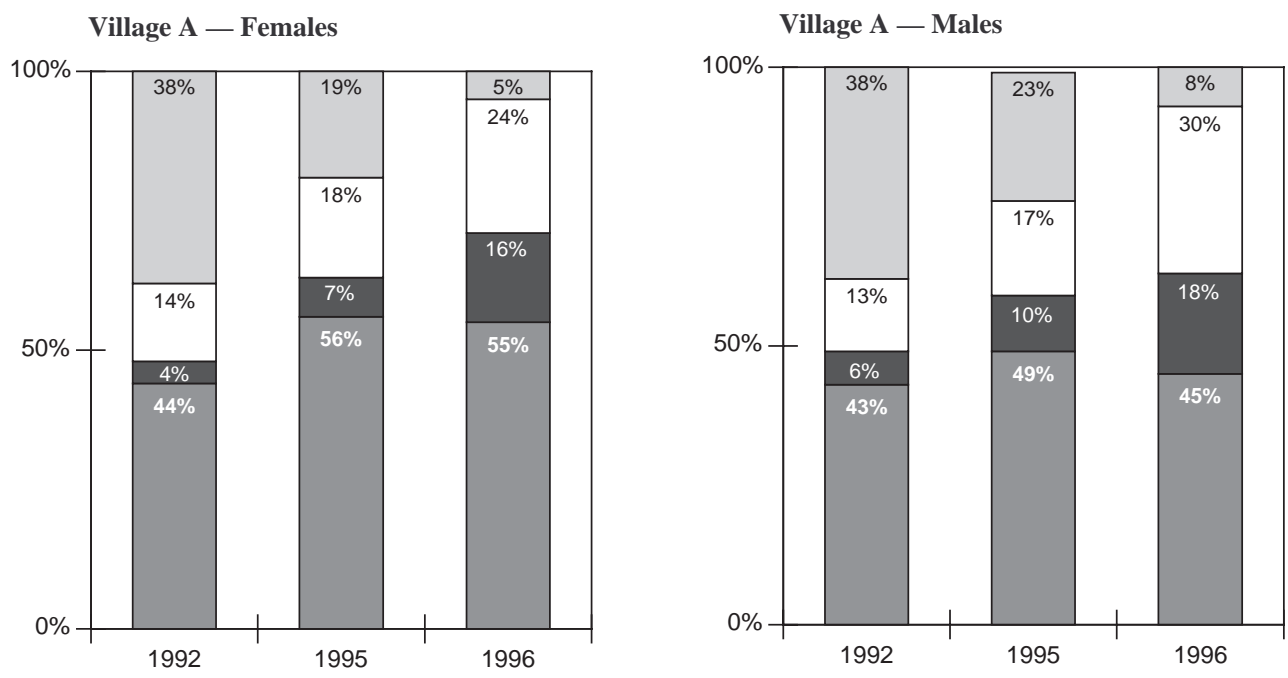

Village B - Females

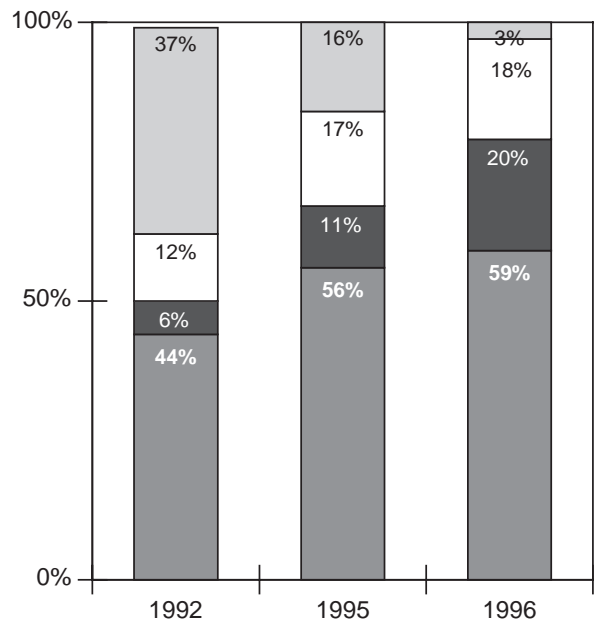

Village B - Males

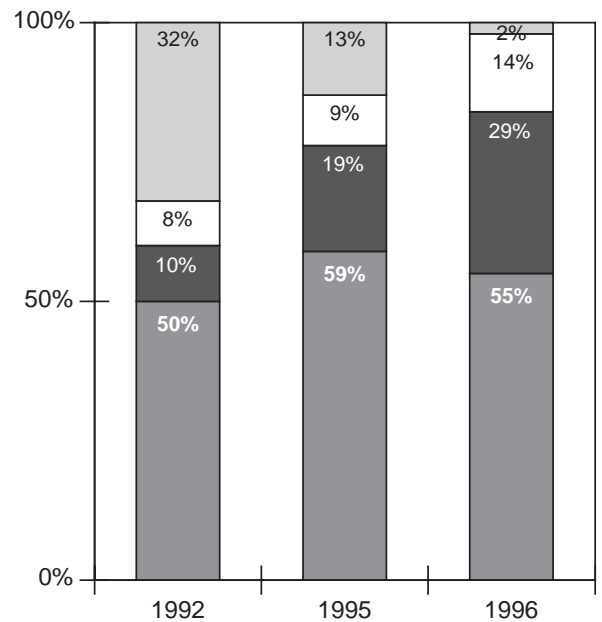

$\square$ Never in school $\quad \square \quad$ No longer in school

In secondary school or above

In primary school

attendance by 1996. For example, boys' enrollment in either primary or secondary school increased from 60 percent in 1992 to 84 percent in 1996 in Village B, compared to a more modest increase from 49 to 63 percent in 
Village A. Thus, as measured by changes in boys' enrollment in Village B compared to Village A, enrollment rose twice as rapidly in the village where food-for-education was introduced.

In Village A we would expect greater improvement for girls than boys, since both programs there - the BRAC schools and the secondary school scholarships - benefited girls more than boys. Enrollment in primary school did improve more for girls than boys in this village, rising from 44 percent to 55 percent among girls and from 43 to 45 percent among boys. In fact, boys in Village A are the only group that was not eligible for benefits from any incentive program, and we observe accordingly that enrollment did not show a sustained improvement among Village A boys from 1992 to $1996 .{ }^{4}$

The two primary school incentive programs - the BRAC school in Village $A$ and the wheat-for-education program in Village B - were available only to poor families, and the principal criterion on which poverty was assessed was landlessness. ${ }^{5}$ A comparison of enrollment trends among the landless families with the trends observed among all families points to the role of the incentive programs in boosting school enrollment. Figure 2 presents the same distributions as Figure 1, based on children of landless families only. Indeed, Figure 2 indicates that in Village B, primary school enrollment levels improved much more among the children of poor families than among children from the village as a whole, although the two groups had similar enrollment levels in 1992. Similarly in Village A the increase in girls' schooling was greater among poor families than in the population as a whole.

Boys from poor families in Village A also experienced an increase in attendance levels, despite the lack of a program aimed directly at them. While this improvement is not as strong as most of the increases experienced by children eligible for programs, it suggests that a general trend toward higher 
Figure 2 School attendance status of 6-19-year-olds in functionally landless households, Mohanpur
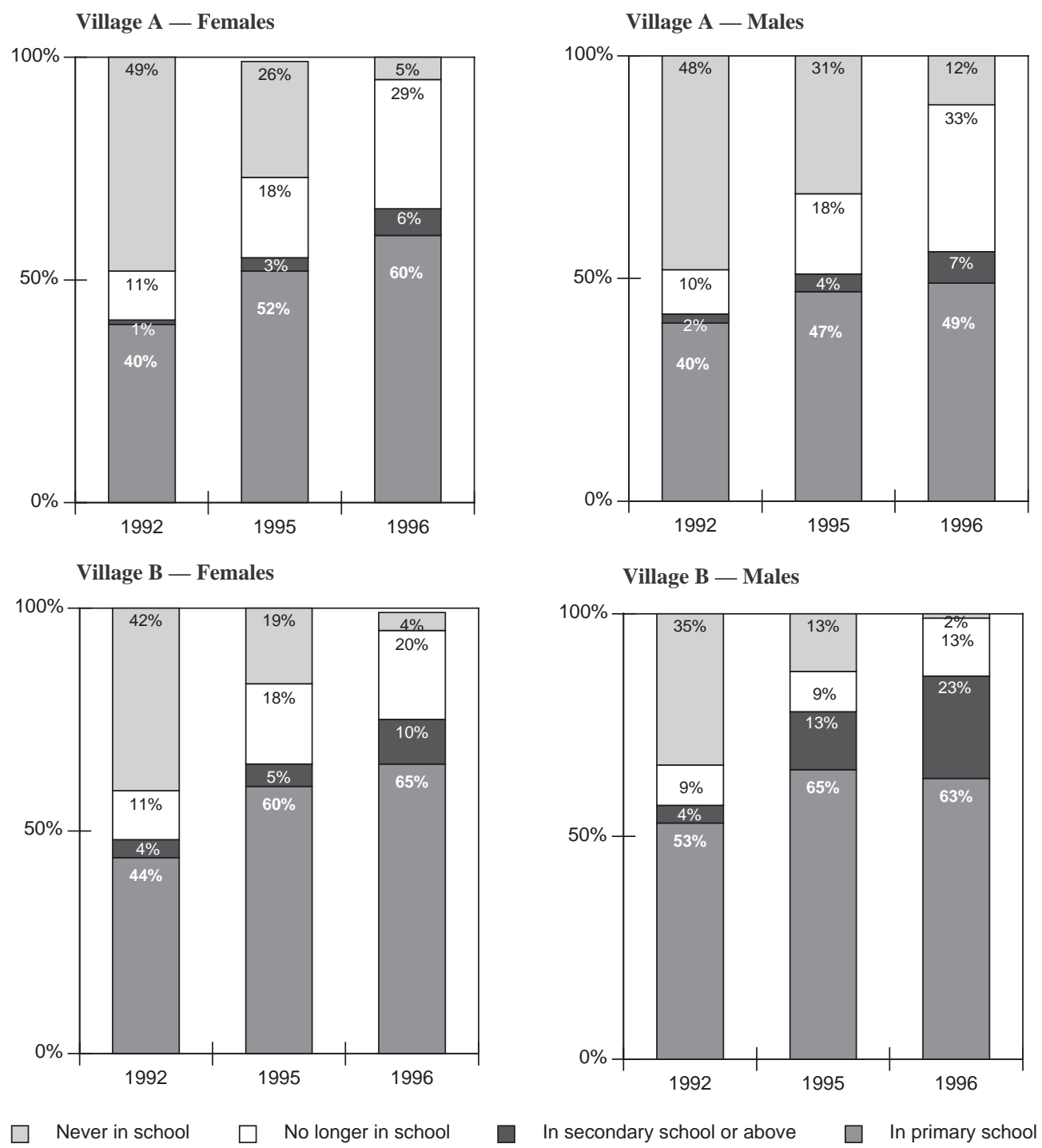

levels of school attendance may have occurred in these communities that was not attributable to the incentive programs. Alternatively, the programs may have had a spillover effect on other children in the community. This is 
likely to operate at the household level when program benefits for girls free up resources that could be invested in boys. It is likely that both of these factors contributed to the observed trends.

Older children in primary school. It is common in Bangladesh for some primary school children to be older than the conventional primary school age. It is also likely that the primary school incentive programs encouraged older children to begin or resume their primary school education. Figure 3 displays the proportion of 14-19-year-old children in primary school in 1992, 1995 and 1996, by village and sex. All groups, with the possible exception of girls in Village B, experienced an increase in proportions enrolled between 1992 and 1995. The most notable increase was among girls in Village A. The BRAC program is most likely responsible for this trend, particularly since the program, available only in Village A, makes a concerted effort to recruit older girls into its accelerated primary school program.

After 1995, the proportion of older children in primary school declined considerably in all groups, reaching levels below those of 1992 (except among girls in Village A). These declines coincided with sharp increases in the proportions of children enrolled in secondary school during the same period (Figure 1). These trends suggest that one of the net effects of the incentive programs has been an improvement in the proportion of children in the level of schooling appropriate to their age.

Primary school completion. Table 2 examines school completion trends over a longer period by comparing age-specific primary school completion rates by three-year age group for all 15-32-year-olds, by sex and village of residence. These rates allow us to examine recent changes in levels of schooling in the context of longer-term trends in education. The rates for the youngest cohorts provide evidence that educational levels have shown substantial re- 
Figure 3 Percent of 14-19-year-olds in primary school

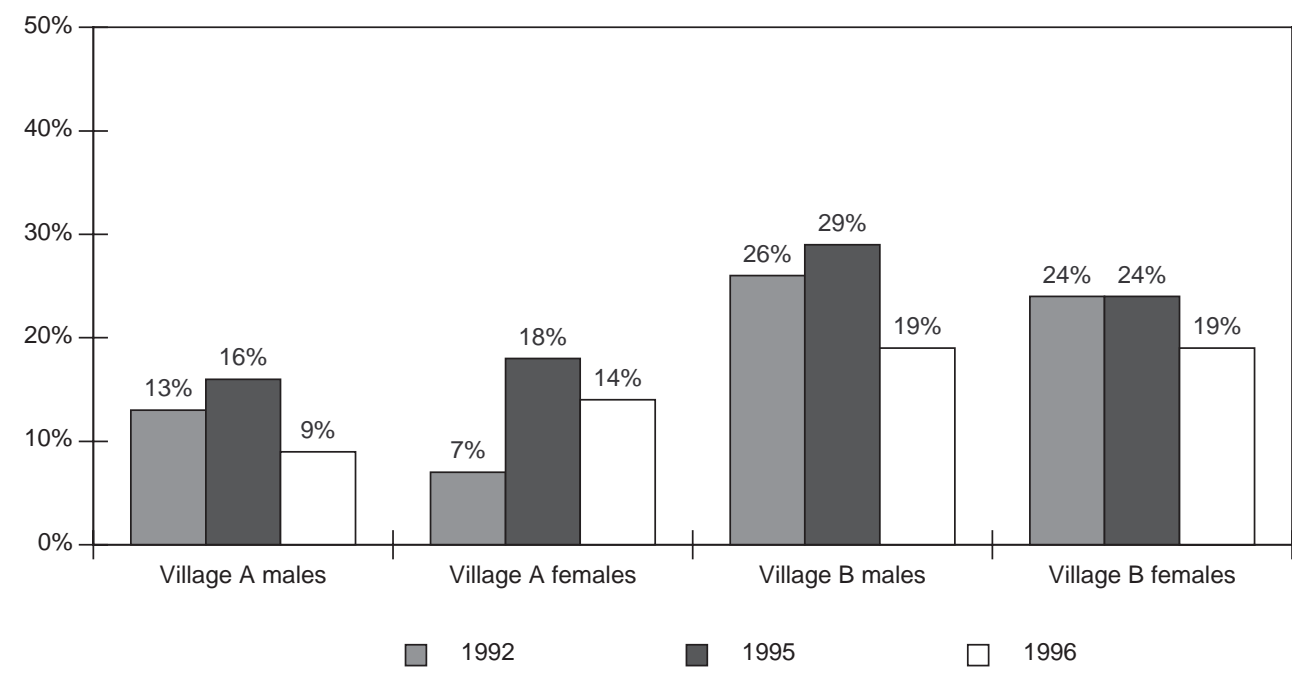

cent increases, in both villages and especially among girls. But, compared to the rates of school completion for earlier cohorts, the evidence also indicates that the primary school completion rate began to increase before the onset of the incentive programs, especially for females in Village A, and also for boys and girls in Village B. While it cannot be established conclusively that the recent improvements in primary school completion would not have taken place in the absence of programs, it remains noteworthy that the groups that were targeted in these programs showed the most improvement. In particular, the high levels of primary school completion among 15-17-year-old girls in both villages in 1995 (roughly 50 percent) seem to surpass the pace of improvements in educational attainment in prior cohorts.

The cohort data indicate that a sudden increase in school achievement for girls began with the cohort entering school in 1976-79 (at the ages of 57 years) and completing primary school in the late 1980s or early 1990s. 
Table 2 Age-specific primary school completion rates (in percent)

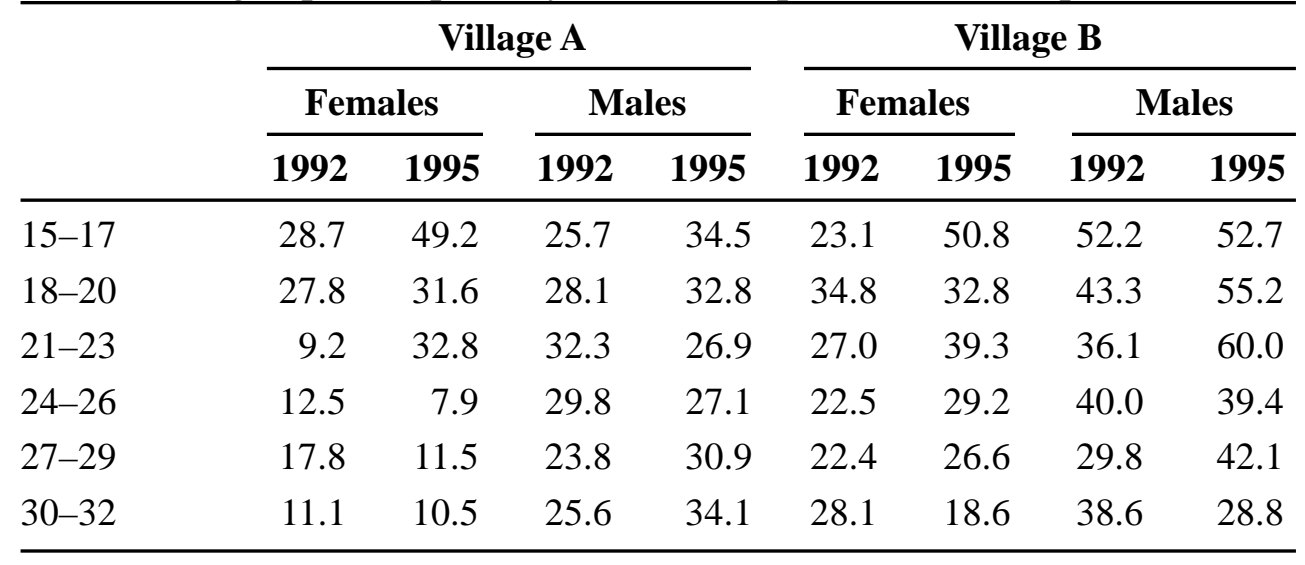

Similar trends have been noted in national data (Ahmed 1995). It is likely that girls' schooling received a boost because of legislation in the mid-1980s that made secondary school free for girls while boys continued to pay fees. Village A may have received an extra boost in female enrollment because of a new girls' school that was opened in the mid-1980s.

Progression to secondary school. The rates of progression to secondary school among those who completed primary school, displayed in Table 3 , indicate that the female secondary school scholarship programs may have motivated an increased propensity to enroll in secondary school among girls in both villages. The gender differential in the rates of progression to secondary school is especially strong in Village A, where the proportion of male primary school graduates enrolled in secondary school increased from 49 percent to 62 percent while the proportion of female graduates proceeding to secondary school increased from 48 to 71 percent. Thus, in Village A girls' entry into secondary school improved at a rate that was almost twice as fast 
Table 3 Percent of primary school graduates enrolled in secondary school, by village, sex, and year

\begin{tabular}{ccccccc}
\hline & \multicolumn{2}{c}{ Village A } & & \multicolumn{2}{c}{ Village B } & \\
\cline { 2 - 3 } & Boys & Girls & & Boys & Girls & Everyone \\
\hline 1992 & 49 & 48 & & 59 & 50 & 63 \\
1995 & 60 & 63 & & 78 & 67 & 72 \\
1996 & 62 & 71 & & 84 & 79 & 76 \\
\hline
\end{tabular}

as the gains in boys' enrollment. Girls showed a higher rate of improvement than boys in Village B as well, although the differential was not as great: the rate of progression among boys increased from 59 percent to 84 percent, while among girls it increased from 50 to 79 percent. The key explanation for the sex differential is thought to be the scholarship program for girls in both villages, as reflected in respondents' quotes presented earlier. But the cohort data also suggest that the female secondary school scholarship program reinforced a rising trend in female education that was already in place. The BRAC school in Village A, which provided an accelerated secondary school preparation program to disadvantaged and uneducated girls, may also have had an indirect effect on secondary school enrollment in that village. The relatively small change in enrollment among boys in Village A reflects the fact that the new programs did not include an incentive for boys to attend secondary school.

Age-specific enrollment levels. Figure 4 depicts the proportion of children in school in each age group - regardless of grade level — by village and sex. The age group showing the greatest improvement in enrollment since 1992 is 6-9 year-olds. Enrollment increases in this age group were 
Figure 4 Enrollment in school by age and years (in percent)
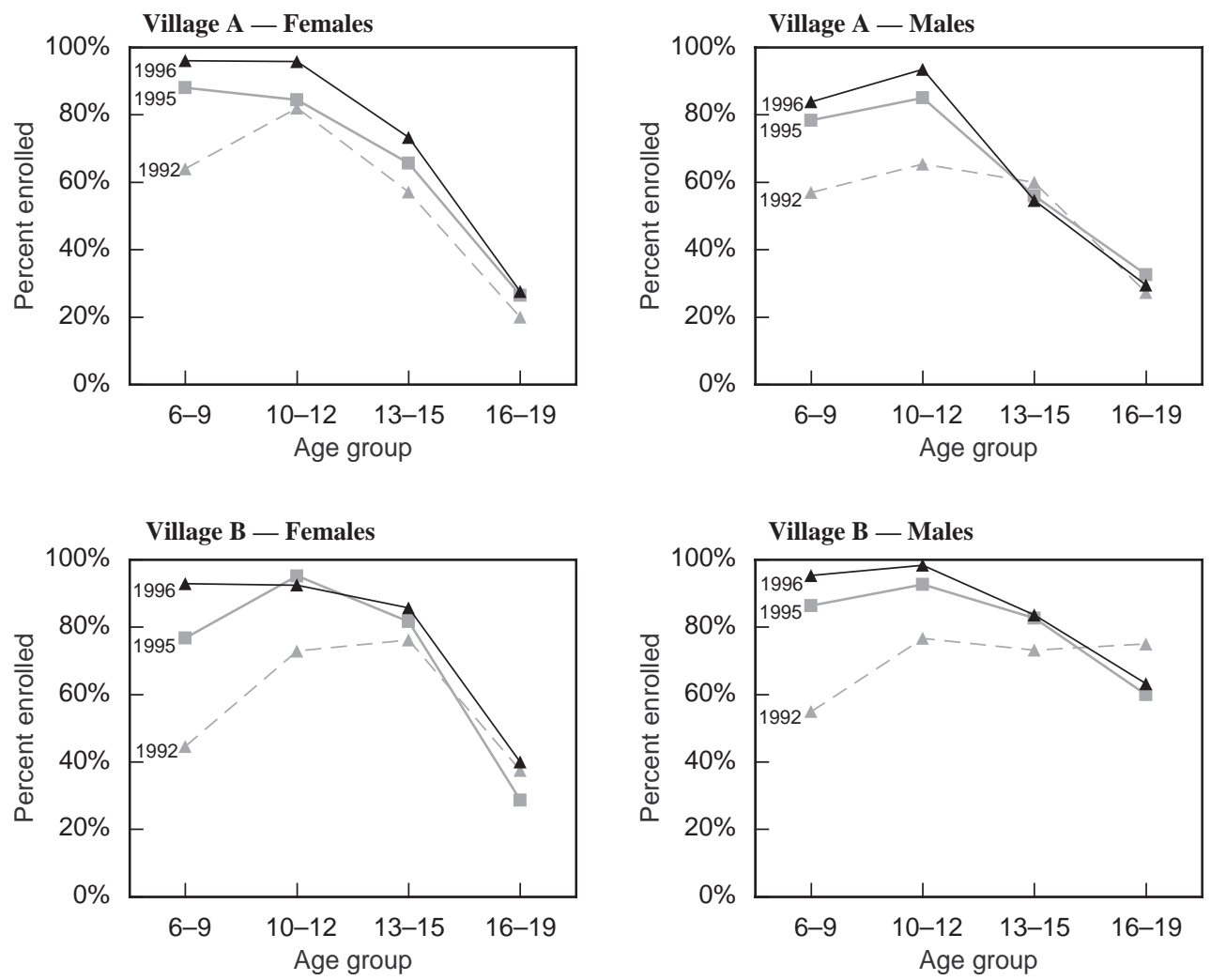

somewhat greater for girls than boys in both villages. At 13-15 years of age, the only group not to see an improvement in enrollment is boys in Village A, who were not eligible for any program benefits. Overall in 1996 more females than males were in school in Village A, and more males than females were in school in Village B.

Overall enrollment in any school among 6-19-year-olds stood at 51 percent in 1992, 67 percent in 1995, and 74 percent in 1996. Even though these rates of enrollment do not correspond to the government's declared 
objective of universal education, it is unquestionable that education is on the rise, and these villages have achieved what Caldwell has described as mass education (1980).

Marriage delays due to increased enrollment. Since early marriage is common in rural Bangladesh, enrollment of girls in secondary school has important consequences for the timing of their marriage. Table 4 shows the percentage of the population under age 30 ever married, by age group. Comparing data before and after the secondary school scholarship scheme went into effect suggests that the introduction of the program had an immediate and significant effect in delaying marriage. The overall proportion of females who are married declined over the relatively short span between 1992 and 1995 from 29 to 14 percent for 13-15-year-olds and from 72 to 64 percent for 16-19-year olds. ${ }^{6}$ There was also an apparent effect on the age at marriage for males in slightly older age groups, probably because in these villages girls are married to men who are on average 7-10 years older than they are. These marriage delays can have significant long-term implications for the status of women, since early ages at marriage and childbearing have

Table 4 Percent of women and men aged 10-29 years ever married, 1992 and 1995

\begin{tabular}{lccccc}
\hline & \multicolumn{2}{c}{ Women } & & \multicolumn{2}{c}{ Men } \\
\cline { 2 - 3 } \cline { 5 - 6 } Ages & $\mathbf{1 9 9 2}$ census & $\mathbf{1 9 9 5}$ census & & $\mathbf{1 9 9 2}$ census & $\mathbf{1 9 9 5}$ census \\
\hline $10-12$ & 6 & 1 & & 0 & 0 \\
$13-15$ & 29 & 14 & & 0 & 0 \\
$16-19$ & 72 & 64 & & 16 & 10 \\
$20-29$ & 94 & 92 & & 71 & 59 \\
\hline
\end{tabular}

Source: Arends-Kuenning and Amin 1998 
long been held to be strongly associated with high gender inequality. Sustained patterns of delayed marriage also have strong implications for the length of generations and can help to slow the momentum of population growth associated with a young age structure.

\section{Grade Progression in School}

While the enrollment figures are encouraging, very few children progress through school at the expected pace. In all three study years a majority of school-age children were not enrolled in a grade appropriate for their age. However, considerable improvement in grade-for-age statistics has occurred for both sexes and in both villages over time. The education histories collected from children in 1996 allow us to estimate the prevalence of the different causes of laxity in grade progression. Of the 1,152 children surveyed in 1996, 42 percent were enrolled in the grade appropriate to their age. Of the children who were not in the proper grade for age, 46 percent were not enrolled in school at all. Of the remaining children in school at a low grade for age, 65 percent had repeated at least one year of schooling, and 35 percent appear to have been lagging in grade-for-age due to delayed entry into school.

Information on trends in the prevalence of late entry into school can be gleaned from Figure 4. In 1992, enrollment levels were much higher for 1012-year-olds than for 6-9-year-olds. We interpret these differentials as the effects of delayed entry, rather than cohort effects, since similar patterns of higher enrollment among an older age group relative to a younger age group are seen in other enrollment data from Bangladesh, such as the 1981 national census data for all rural children. Age-specific enrollment rates for 1992, 
1995, and 1996 in the study villages show an increase in young age enrollment and suggest that the incidence of delayed entry has declined considerably. By 1996 enrollment levels for 6-9-year-olds were much closer to levels for 10-13-year-olds, as children increasingly began school at younger ages. There appears to have been a substantial decline in the incidence of delayed entry among girls in both villages, and among boys in Village B. Boys in Village A seem to be the only group in which the incidence of late entry has not changed markedly, despite substantial improvements in enrollment levels for 6-12-year-olds. Again, boys in Village A are the only children who were not targeted by an incentive program, and it appears that the programs contributed to an increasing tendency to begin school at an early age among the other subgroups in the population.

Data on grade repetition are not available before 1996. According to the 1996 data, 67 percent of respondents in Village A had repeated a year or more of their schooling, along with 50 percent in Village B. Among children of primary school age in Village B, those who were benefiting from the food-for-education program were just as likely to have repeated a grade as those not in the program. Thus, although there was some speculation that parents would try to prolong their access to program benefits by holding their children back in primary school, the lower incidence of grade repetition among food-for-education recipients in Village B disproves the thesis of voluntary retention among program beneficiaries.

While girls in government schools were far more likely than boys to have repeated a grade in both villages, this differential was much smaller in Village A. Parents in Village A may have begun to encourage grade progression for their daughters, so as to take advantage of the scholarship program 
available only in secondary school. This finding suggests that the secondary school scholarship program may have begun to act as an incentive for girls to progress through primary school, particularly where the food-for-education program is not available.

\section{Impact of Schooling on Gender Differentials in Learning}

Concern has been expressed that while girls' education may be getting a boost through financial incentives, girls may continue to be disadvantaged in terms of actual learning because of lack of attention to girls in school or lesser time devoted to schoolwork. To measure the levels of learning associated with schooling and to assess gender differentials in learning, a series of questions was put to each respondent in the 1996 survey, covering knowledge of the world-at-large, agriculture, primary health, and numeracy. When respondents' scores on these 17 questions were assessed, the average number of correct answers for boys was higher than for girls (50 percent vs. 43 percent). Boys scored better than girls in all areas except for health, and they far surpassed girls in numeracy (scoring 71 percent vs. 48 percent).

Despite these overall gender differentials favoring boys, girls appear to benefit more from each additional year of school relative to boys. The rate of score improvement with schooling differed between the sexes in numeracy, agriculture, and contraceptive knowledge (see Table 5). Each additional grade level attended resulted in a greater improvement in girls' scores than in boys' scores in numeracy and contraceptive knowledge, while boys outpaced girls in knowledge of agriculture. While some effects of the duration of schooling on test scores may reflect selective retention in school of children of higher 
Table 5 Effect of duration of schooling on test scores, by sex, 1996

\begin{tabular}{lcccc}
\hline $\begin{array}{l}\text { Five additional } \\
\text { years of schooling }\end{array}$ & $\begin{array}{c}\text { Total test } \\
\text { score }\end{array}$ & $\begin{array}{c}\text { Numeracy } \\
\text { score }\end{array}$ & $\begin{array}{c}\text { Agriculture } \\
\text { score }\end{array}$ & $\begin{array}{c}\text { Contraception } \\
\text { score }\end{array}$ \\
\hline For girls & +18.89 & $+29.83 *$ & $+4.47 *$ & $+10.00 *$ \\
For boys & +20.63 & $+20.65 *$ & $+10.82 *$ & $+5.22 *$ \\
\hline
\end{tabular}

Note: Predicted test scores are estimated from multivariate regression where age, socioeconomic characteristics, village, and enrollment in BRAC vs. government schools are held at their actual vales and education is changed by five years.

*Modification of effect of schooling by gender was statistically significant.

aptitude, we have shown that enrollment increased in response to financial incentives in a way that would lessen the impact of selection on aptitude.

Separate estimates of the association between test scores and duration of schooling in each subject area revealed that educational level had a relatively strong impact on knowledge of world facts and on numeracy for both sexes (see Figure 5). The relationship between educational level and knowledge of agriculture was of a much lower magnitude; it is likely that knowledge pertaining to agriculture is expanded as much through productive work at home as through school. Grade level also had a relatively small, though significant, impact on health knowledge.

Respondents, who ranged in age between 6 and 19, were also tested on their knowledge of six types of contraception. On average each person knew of two methods. For comparative purposes, respondents' performance on questions about family planning were also assessed on a percentage scale. Each grade level attended was associated with a modest improvement in test scores of about 1.5 percentage points. The small role of formal education in children's knowledge about contraception is consistent with the evidence that family planning information is disseminated largely through public edu- 
Figure 5 Test scores in various subject areas by highest grade level attended

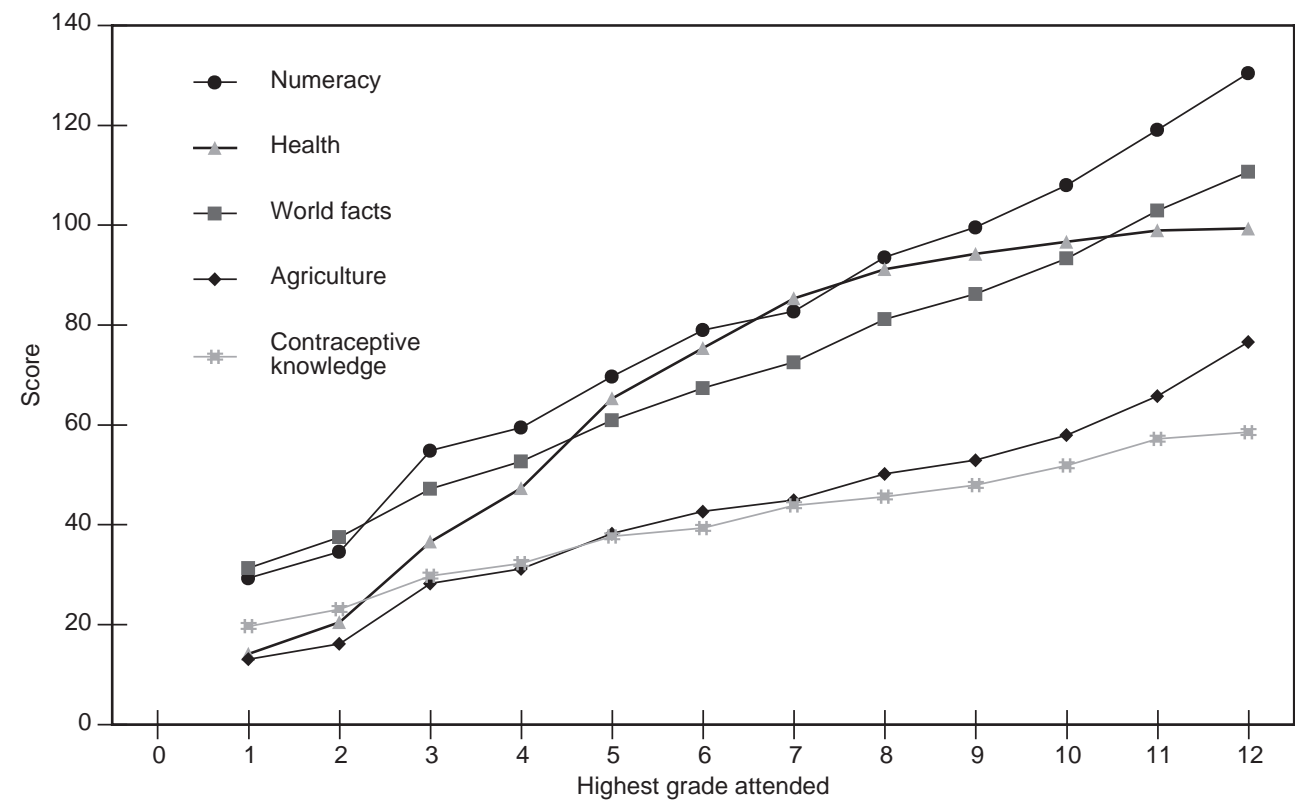

Note: Test scores were predicted from models that included controls for socioeconomic characteristics, sex, age, village, and type of school attended (government vs. non-government).

cation campaigns and family planning programs. Fertility surveys indicate widespread knowledge of contraceptive methods among ever-married women, and it is likely that the same source of information has affected knowledge about contraception among children as well.

\section{Costs of Schooling}

The principal aim of the government-sponsored incentive programs was to encourage better education by reducing the cost of educating children 
in Bangladesh. The indirect costs of schooling, such as the decrease in children's time available for productive work, are also important considerations for most families. In this section and the next we present evidence on the direct costs of schooling, and on the opportunity cost of schooling in terms of children's labor. Data on school costs collected in the 1996 survey showed that while the direct cost of educating girls was lower than for boys, the indirect costs in terms of less time available for income-earning work is considerable higher for boys.

Direct costs of schooling. In 1996, respondents were asked about expenditures on school fees, books and supplies, and clothing for the year prior to the survey. Clothing costs were the largest expense for children of all ages, followed by outlays for books and supplies. School fees, including monthly, annual, and exam fees and costs of school-related activities, actually comprised a small proportion of total expenditures. The secondary school scholarship scheme affected the reported costs of direct school expenses such as examination fees, since these fees are paid to the school by the government. Similarly, all children attending BRAC schools have lower reported costs because they receive all their books and supplies from the school.

Figure 6 shows predicted costs for boys and girls estimated from a multivariate model according to whether or not the child is enrolled. The differential in expenditures between students and non-students is greater for boys than for girls, suggesting it is more expensive to educate boys. The lower additional cost of sending a girl to school relative to keeping her at home, compared to the additional cost involved in educating a boy, may be attributed to a couple of factors. The secondary school scholarship program and the BRAC school program subsidize girls more than boys; on the other 
Figure 6 Predicted annual total costs per child, by sex and age, according to whether or not child is enrolled in school

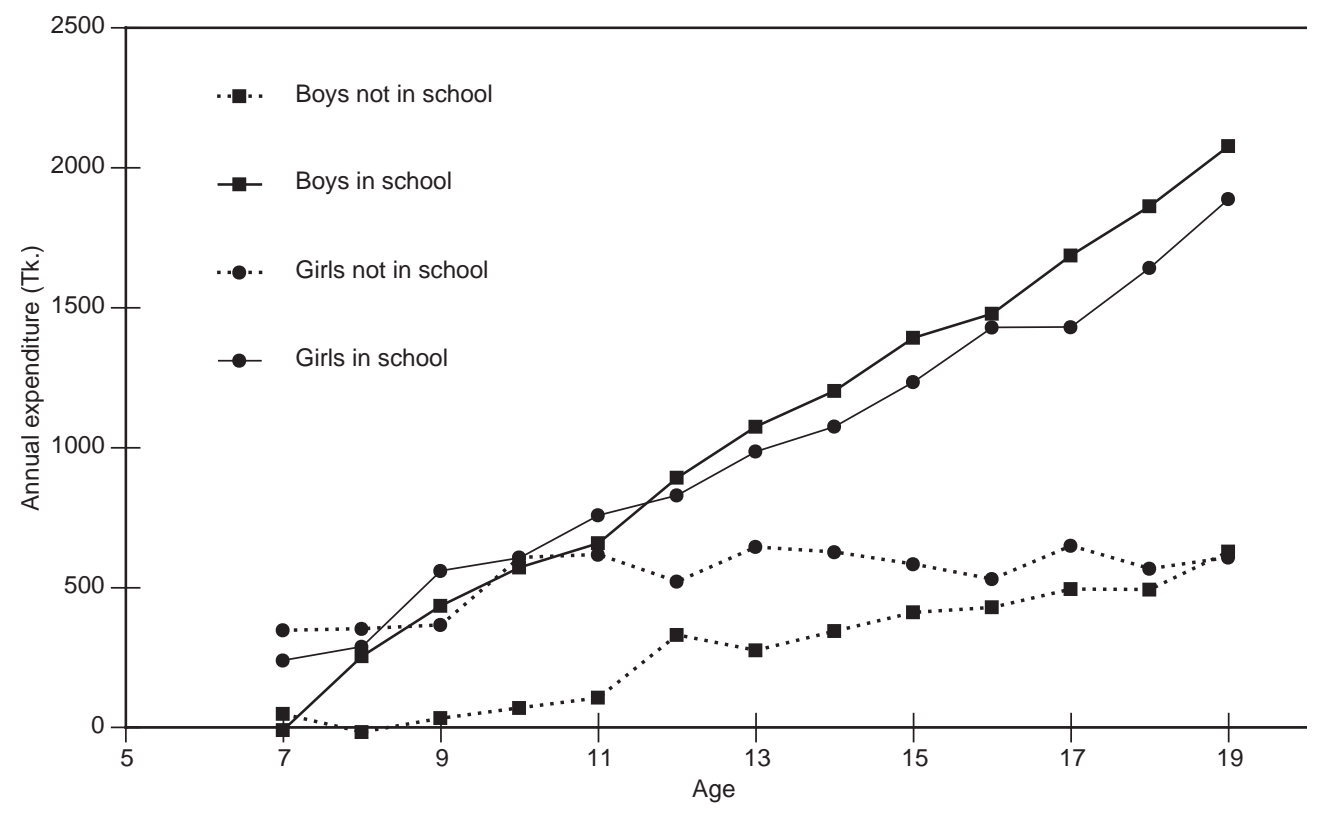

Note: Expenditures were predicted from models that included controls for socioeconomic characteristics and village. Differences by sex and enrollment status were statistically significant.

hand, clothing expenditures were higher for girls relative to boys of the same age, whether they were in school or not, presumably because concerns about appearance set higher standards of dress for girls of marriageable age. Thus, the additional cost of schooling as a proportion of total expenditures for a girl, while probably still prohibitive in the eyes of many parents, is not as great as the corresponding cost for boys, and certainly considerably smaller than the cost before the establishment of the secondary school incentives. The figure also shows a sharp rise in school expenditures with age, probably attributable to the high costs of books and uniforms in secondary school. 
The in-depth interviews included discussions with recently married girls on the circumstances surrounding their marriage. Several cases suggest that cost considerations were the reason for dropping out of school during marriage negotiations. One of our respondents, a 16-year-old girl who was recently betrothed, dropped out of school when, four months after the school year began, her father had not paid for her books. The girl was ineligible for the scholarship scheme at the time. Her father was negotiating her marriage and was reluctant to incur the significant expenses that her books would require. Since the father was hoping to get his daughter married before the end of the year, he assumed the books would be a waste because she would not be able to finish the school year. Our data show that since stipend programs came into effect there has been an increase in female education that continues into the adolescent years, the time when marriage negotiations take place. While it is unlikely that stipends fundamentally alter parental values on early marriage, they may induce parents to allow girls to stay in school during marriage negotiations because now it is less costly to do so.

Time demands on children. In 1992, detailed data collected on timeuse patterns show that the amount of time spent in school is low for children and adolescents. These low time requirements for schooling may explain why children who go to school continue to have significant work input in the household. Time requirements for school attendance are low in the Bangladesh school system, with the total number of hours spent being among the lowest in the world (see Ahmed 1995). ${ }^{7}$ One reason for low hours is doubleshifting, in which the same space and teachers serve two groups of children each day. Table 6 shows estimates of time spent in school by children who attended school. Children in the 6-9-year age group spend less than 2 hours 
Table 6 Hours spent in school by age group, 1991

\begin{tabular}{lcc}
\hline Age group & Male & Female \\
\hline $6-9$ & 1.96 & 1.99 \\
$10-12$ & 2.45 & 2.49 \\
$13-15$ & 3.08 & 2.53 \\
$16-19$ & 4.18 & 4.45 \\
\hline
\end{tabular}

on days that they do attend school; even children aged 16-19 years spend only 4 to 4.5 hours in school.

\section{Perceptions of the New School Programs}

The in-depth interviews provided some additional, less quantifiable information on the changing environment with regard to schooling in the study villages. The introduction of incentives appears to have reinforced the value of education. A rhetorical question that we heard repeatedly from parents and children in response to a general question on the value of education was "Why would the government pay the poor to go to school, or girls to go to secondary school, if it was not important?"

Similarly, the fact that the female secondary school scholarship program requires families to sign a bond that marriage will be delayed until age 18 seems to be legitimizing later marriage. One parent said she believed the ideal age at marriage for girls was 20 years. Since the usual marriage age for the study area is 15-16 for girls and 20-25 for boys, she was asked to ex-

plain why. Her response was: "Why else would the government try so hard by giving scholarships to girls?" 
The targeting of programs to girls, children from poor families, and school dropouts appears to have introduced the idea that education is a universal right, whereas in the past it was considered a prerogative of those who could afford it. One of the effects of the incentive programs in Bangladesh, and indeed the aim of the program, is to make education widely accessible regardless of social class and gender.

Discussions on the value of education reflected these changing attitudes. In addition to such benefits as access to modern-sector jobs and higher-status occupations, schooling was also spoken of as a necessity in everyday rural life. This perception of education as a necessity even for poor agricultural laborers is likely to be related to the new emphasis on mass education, brought about in part by the introduction of special incentives for underprivileged groups. It is likely that the recent expansion of micro-credit programs and other development initiatives that carry direct messages about the benefits of gaining minimal literacy may also have reinforced this new notion of schooling as a functional tool that is relevant even for a poor peasant farmer.

\section{CONCLUSION}

There has been a sharp rise in school enrollment in the study villages in recent years. We have argued that several recent interventions in the education system in Bangladesh, and two incentive schemes targeted to disadvantaged groups in particular, have contributed to the rising enrollment. Other factors that may be at work are special schools run by NGOs for school dropouts. The incentive schemes appear to have increased enrollment over and above a rising trend in schooling that has been evident for a longer pe- 
riod. Although the programs have been in place for only a few years, there is strong evidence that they have succeeded, as well, in delaying marriage.

Two other indicators of improvement in school attendance in 1995 and 1996 relative to 1992 are higher proportions of children enrolled in grades appropriate for age and higher proportions entering school at age six. However, a 1996 study showed that the majority of students who were behind had repeated grades at least once, and some proportion of children still started school at later than recommended ages. Our data on aptitude scores confirm that the quality of education in village schools was poor relative to schooling in urban Bangladesh. The data showed that while boys have higher test scores than girls, schooling contributes significantly to boys' and girls' ability to learn, as measured by the responses to a set of test questions. In particular, although girls tend to score lower than boys on average, they gain more per year of schooling relative to boys.

In these villages children can still make significant contributions to the family economy while attending school, largely because the time demands for school are low. Expenditure data confirm that the incremental cost associated with sending a girl to school is now less than that associated with sending a boy to school, because of the special subsidies available for girls in secondary school.

Our qualitative data suggest there may be a less tangible but more sustained impact of these programs on the way education is valued. By establishing a pattern of school-going and expanding knowledge of the school system, these schemes may well have removed certain barriers to the promotion of mass education. These educational interventions may have allowed the villages to enter the initial stages of mass education as described 
by Caldwell (1980). The various programs reinforce the message that schooling is a high priority for the government and valuable for the individual. The qualitative data suggest that although the incentives were designed to allow households to overcome financial and other barriers to education, they may also have brought about a significant ideational change with regard to schooling.

\section{Notes}

1. The Thana is an administrative unit with an average population of about 230,000 in 1991. Each Thana has eight Unions.

2. BRAC has developed a franchise-like model through which they provide financial and technical assistance to local institutions to set up schools.

3. Wheat prices ranged from Tk. 5.50 to Tk. 10.00 in 1992. We estimate that the wheat ration amounted to approximately 7 percent of average monthly income in these villages.

4. In 1995 boys' enrollment increased to 49 percent, before dropping to 45 percent in 1996. Expectations were raised in 1995 that the village would be included in the wheat-for-education program, and there was some disappointment when that did not materialize.

5. Landlessness was defined as owning 0.5 acres or less of agricultural land.

6. For a discussion of marriage delays associated with the introduction of education incentives see Arends-Kuenning and Amin 1998. 
7. In addition to month-long summer and winter vacations, there is usually a month off for Ramadan and, in secondary school, another month off during the 10th grade examination. The first month of the school year has low attendance, since teachers are expected to conduct a community-wide survey as part of an enrollment drive, and various school events take place such as sports and prize distribution days. The school year averages about 220 days in length.

\section{References}

Ahmed, Muzaffar. 1995. Experience with Economic Reform: A Review of Bangladesh's Development 1995, in Sobhan 1995.

Amin, Sajeda. 1996a. "Female education and fertility in Bangladesh: The influence of marriage and the family," in Roger Jeffery and Alaka M. Basu (eds.), Girls'Schooling, Women's Autonomy and Fertility Change in South Asia. New Delhi, London, and Newbury Park: Sage Publications.

Amin, Sajeda. 1996b. "Family structure and change in rural Bangladesh," Research Division Working Paper No. 87. New York: Population Council.

Amin, Sajeda. 1997. “The poverty-purdah trap in rural Bangladesh: Implications for women's roles in the family," Development and Change 28(2): 213-233.

Amin Sajeda and Mead Cain. 1997. "The rise of dowry in Bangladesh," in G.W. Jones et al. (eds.), The Continuing Demographic Transition, pp. 290-306. Oxford: Clarendon Press.

Arends-Kuenning, Mary and Sajeda Amin. 1998. "Effects of schooling incentive programs on household time allocation," paper presented at the Annual Meeting of the Population Association of America, Chicago, April 2-4. 
Caldwell, John C. 1980. "Mass education as a determinant of the timing of fertility decline," Population and Development Review 6(2): 225-255.

Sobhan, Rehman. 1995. Experience with Economic Reform: A Review of Bangladesh's Development 1995. Dhaka: Center for Policy Dialogue and University Press Limited. 


\title{
POLICY RESEARCH DIVISION WORKING PAPERS
}

\author{
Recent Back Issues
}

1996

*83 Sajeda Amin, Ian Diamond, and Fiona Steele, "Contraception and religious practice in Bangladesh."

84 John B. Casterline, Aurora E. Perez, and Ann E. Biddlecom, "Factors underlying unmet need for family planning in the Philippines."

85 Geoffrey McNicoll, "Governance of fertility transition: Regularity and duress."

*86 John Bongaarts, "Population pressure and the food supply system in the developing world."

87 Sajeda Amin, "Family structure and change in rural Bangladesh."

*88 John Bongaarts and Susan Cotts Watkins, "Social interactions and contemporary fertility transitions."
*89 Cynthia B. Lloyd and Mark R. Montgomery, "The consequences of unintended fertility for investments in children: Conceptual and methodological issues."

* 90 Zeba Sathar and Sonalde Desai, "Work patterns in rural Pakistan: Intersections between gender, family, and class."

91 Mark R. Montgomery, "Learning and lags in mortality perceptions."

92 Ann E. Biddlecom, John B. Casterline, and Aurora E. Perez, "Men's and women's views of contraception."

* No longer available 
93 James F. Phillips, Fred N. Binka, Martin Adjuik, Alex Nazzar, and Kubaze Frank Adazu, "The determinants of contraceptive innovation: A case-control study of family planning acceptance in a traditional African society."

94 John Bongaarts and Sajeda Amin, "Prospects for fertility decline and implications for population growth in South Asia."

95 Barbara S. Mensch and Cynthia B. Lloyd, "Gender differences in the schooling experiences of adolescents in low-income countries: The case of Kenya."

96 Martin Brockerhoff and Ellen Brennan, "The poverty of cities in the developing world."

97 Carol E. Kaufman, "Reproductive control in South Africa."

98 John Bongaarts, "Trends in unwanted childbearing in the developing world."

99 Mary Arends-Kuenning, "How do family planning workers' visits affect wom- en's contraceptive behavior in Bangladesh?"

100 Mark R. Montgomery and Cynthia B. Lloyd, "Excess fertility, unintended births, and children's schooling."

101 Mary Arends-Kuenning, "The equity and efficiency of doorstep delivery of contraceptives in Bangladesh."

102 Sajeda Amin, Ian Diamond, Ruchira T. Naved, and Margaret Newby, "Transition to adulthood of female factory workers: Some evidence from Bangladesh."

103 Margaret E. Greene and Ann E. Biddlecom, "Absent and problematic men: Demographic accounts of male reproductive roles."

104 Michael P. Todaro, "Urbanization, unemployment, and migration in Africa: Theory and policy."

105 Geoffrey McNicoll, "Population and poverty: A review and restatement."

1998

106 Sajeda Amin and Gilda Sedgh, "Incentive schemes for school attendance in rural Bangladesh." 